\title{
Classroom Management at Preschool Level: An Overview from Pre-Service Teachers' Perspectives
}

\author{
Mehmet Koçyiğit \\ Asst. Prof. Dr., Afyon Kocatepe University, mkocyigit@aku.edu.tr \\ Eray Ĕ̆mir \\ Asst. Prof. Dr., Afyon Kocatepe University, eegmir@aku.edu.tr \\ Cahit Erdem \\ Asst. Prof. Dr., Afyon Kocatepe University, cerdem@aku.edu.tr
}

\begin{abstract}
This study set out to examine student misbehaviors confronted in preschool classrooms, intervention types to these misbehaviors, and the problematic areas that pre-service teachers experienced in preschool classroom management during teaching practice based on senior preservice preschool teachers' observation and experiences during teaching practice course. To this end, in this case study, data were collected from six pre-service preschool teachers through a semi-structured form and weekly meetings. The data were analyzed through descriptive analysis. Some of the basic findings of the study indicate that: peer violence, bad language, not participating to activities and constant yelling/crying are the most prevalent misbehaviors at preschool level; relaxing/punishment corner, one-to-one talking/forcing to apology, and raising voice are the most frequent intervention types. The number of students and catering to children's levels are the most frequent problems the pre-service teachers experience in teaching practice. The problems are related to intrinsic and extrinsic factors. The results are discussed with the literature and recommendations are made.
\end{abstract}

Keywords: classroom management, preschool education, student misbehaviors, pre-service teachers, teaching practice

\section{INTRODUCTION}

Preschool education is a period involving a critical span from the children's birth to primary school in which their cognitive, affective and psychomotor development is fulfilled substantially (Bilir, 1993). Children at this age perceive the external surroundings and realize that these surroundings have peculiar sets of rules. Within this period, children also learn about protecting themselves and their rights, sharing, expressing themselves and respecting others' rights (Yavuzer, 2006). Thanks to preschool education, children gain basic knowledge and skills that help them adapt to life. Due to these reasons mentioned, preschool period is an education level that needs to be practiced in a systematic way in the light of scientific principles (Akgün, Yarar \& Dinçer, 2001).

One of the significant functions of preschool education is to prepare the children for the primary school and offer a supportive education setting for children coming from disadvantaged groups. Research proves that children who have attended preschool education have a higher level of readiness in the primary school level (Taba et al., 1999). An effective education setting is extremely needed for the preschool education, which includes education and instruction practices in a highly critical span for 
children, to result in sound outputs. In this sense, in preschool education, instructional activities need to be designed in accordance with children's development, and education settings should be designed in a way that children have the opportunity to express themselves naturally through getting guidance (Özyürek, 2013).

Herein, arrangement of learning environment and maintaining teacher-student interaction based on a set of principles are considered in the scope of classroom management. Classroom management is a systematic application process of a theory regarding planning, guiding, application and evaluation actions to realize specific goals (Erdoğan, 2001). Classroom management is the first phase of educational administration and an important factor defining the quality of educational administration (Başar, 2001); besides, it is a cardinal element defining a flourishing teaching career (Soleimani \& Razmjoo, 2016, p. 51). It involves principles towards making educational settings psychologically positive and physically secure, appropriately guiding students' behaviors, and ensuring regularly progress of activities in the class (Carter \& Doyle, 2006; Manning \& Bucher, 2013; Weinstein, Romano \& Mignano, 2011).

Teachers do not choose their classrooms. However, they do have control over the kind of classroom atmosphere they construct with their students and the kinds of instructional practices they utilize (Yazdi, Ghanizadeh, \& Mousavi, 2019, p. 39). Management of the classroom in which education and instruction are practiced is intensively affected by factors such as teachers' professional competencies and educational beliefs as well as the quality of pre-service teacher education (Celep, 2002). Considering these factors, it can be suggested that one of the most effective elements of classroom management, which focuses on the progression of education in the favored direction, is the teacher. Regarding the context in preschool education, one of the most essential issues of classroom management is to establish appropriate rules that can be internalized by all students (Hännikäinen, 2007). In preschool education, in-class rules are named as agreement, and students' adoption of these rules, settled by teachers together with students, contributes positively to classroom atmosphere (Durmuşoğlu Saltalı \& Arslan, 2013).

An element of having an effective classroom management skill is to intervene in student misbehaviors successfully. Behaviors that disturb the classroom order, hinder the flow of education and instruction and affect in-class communication negatively are called student misbehaviors (Erol, 2006). It is important for the teacher to identify the reasons of student misbehaviors, predict potential misbehaviors and eliminate them when they arise with an effective strategy (Erdem \& Koçyiğit, 2019). What teacher needs to do in this case is to practice the behavioral change in children by using appropriate methods considering children's interests and requests as opposed to a reactive and interfering approach (Akgün, Yarar v\& Dinçer, 2011; Öngören Özdemir \& Tepeli, 2016).

To cope with the student misbehaviors, teachers can resort to strategies such as trying to understand the problem, ignoring, warning, using punishment and reward, making changes in classroom settings or instructional methods, sharing responsibility with students, and communicating with parents or school administration (Erdem, 2019; Gangal, 2013). Selecting the most appropriate strategy among these and practicing it vigorously is critical for effective instruction (Celep, 2000). Accordingly, "management of instructional process" is regarded as the sub-dimension of "professional competence" area in "General Competencies for Teaching Profession", which is defined as a teacher's knowledge, skill, attitude and personality characteristics needed for an effective performance in various instructional settings by Ministry of National Education (MoNE) (2017). Similarly, in the preschool education curriculum published by MoNE (2013), it is suggested that teachers should be able to provide guidance to children while managing the classroom in education setting that are designed in line with democratic education approach. 
That classroom management is an area in which in-service and pre-service teachers experience problems is highlighted in the literature (Avşar, 2011; Ergünay, 2018; Güney, 2018; Karadağ, 2015; Özaydın \& Çolak, 2011; Sezer, 2006). Therefore, this study aims to reveal the student misbehaviors confronted in preschool education, pre-service preschool teachers' experiences and opinions regarding coping with student misbehaviors and actions to prevent these behaviors during the teaching practice course in which they made observations and teaching practices for one semester. It is expected that the findings of the current study will unearth which strategies are made use of in preschool education institutions, the effect of these strategies and pre-service teachers' perceptions regarding their own competence to use these strategies. To this end, the research questions are as follows:

1. What are the student misbehaviors in preschool classrooms?

2. What are the intervention strategies to misbehaviors in preschool classroom management and to what degree are these strategies are successful?

3. What are the problematic areas that pre-service teachers experienced in preschool classroom management during teaching practice?

\section{METHOD}

This is a qualitative case study. Case study "investigates a phenomenon within its real-life context, especially when the boundaries between phenomenon and context are not evident” (Yin, 2003, p. 13). Students' misbehaviors at preschool level, the intervention strategies and pre-service teachers' experiences and perceptions are explored in the current study within the real classroom context thanks to teaching practice course. The data were collected from six pre-service preschool teachers, selected through convenience sampling, attending to teaching practice course in two preschool institutions. The data were gathered in two phases. First, the participants were asked to report on their practice days through a semi-structured form developed by the researchers. Second, weekly meetings were held with them and they were asked to reflect on the answers they provided in the form.

\section{Participants}

The participants of the current study are six senior pre-service teachers, two males and four females, studying at the pre-school education teaching department at Afyon Kocatepe University and attending the teaching practice course in the spring semester of 2018-2019 academic year. Two of them had the teaching practice in a preschool institution located in Gazi neighborhood in Afyonkarahisar city center. In their practice classroom, there were 11 female and 13 male children. The other four participants had their teaching practice in a nursery class in a primary school located in Hattatkarahisar neighborhood which is closer to the city center. There were 10 female and 15 male students in this class.

\section{Instrument}

The participants were provided with a semi-structured form developed by the researchers and they were asked to express their observations and experiences in line with the questions in the form. The participants were asked to answer the following question each week:

1. What were the student misbehaviors (e.g. naughtiness, bad language, violence, yelling, crying) that attracted your attention during your practice today?

2. Were there any interventions to these misbehavior(s)? Who? How? Was the problem resolved?

3. What were the attitudes, interventions, effective or ineffective methods of the practice teacher or your friend (if s/he was practicing)? 
4. Were there any challenges, problems or surprises in your practice or observation? Did you have any working or not working methods? What were they? Which difficulties did you have in classroom management?

\section{Data collection and analysis}

The data were regularly collected for 12 weeks during which the pre-service teachers went to practice schools between 25.02.2019 and 13.05.2019. The data collected each week were first confirmed with the participants at the meeting in the related week and then they were transferred to computer. The data were analyzed through descriptive analysis. During coding process, cross check was carried out between researchers to ensure coherency. For interrater reliability, Miles and Huberman (1994) interrater agreement co-efficient was calculated and it was found as .80.

\section{FINDINGS}

\section{Findings Regarding Student Misbehaviors in Preschool Classrooms}

First, the data regarding the first research problem were examined and the results are provided in Table 1.

Table 1

Student Misbehaviors and the Number of Their Occurrences

\begin{tabular}{ll}
\hline Misbehavior & Number of observations \\
\hline Peer violence & 7 \\
Bad language & 6 \\
Not participating to activities & 4 \\
Constant yelling/crying & 4 \\
Crying for mother & 2 \\
Not picking up toys & 2 \\
Rebelling/hitting to teacher & 2 \\
Pee one's pants & 1 \\
Disturbing peers' play & 1 \\
Making up excuses & 1 \\
Disobeying rules & 1 \\
Sulking & 1 \\
Breaking toys & 1 \\
Running in the class/disorder & 1 \\
Complaining about peers & 1 \\
\hline
\end{tabular}

As evident in Table 1, the most frequent misbehavior displayed by the preschool students is violence towards peers. These behaviors mostly involve pushing friends, spitting, hitting or throwing toys at them. The second most frequent misbehavior is swearing or using bad language towards peers. Not participating to activities and constant crying and yelling are among the prevalent misbehaviors. Some of the answers provided by the participants regarding student misbehaviors are listed below.

K1: ...throwing legos happened again. Legos were taken away from students and they were banned from playing. A student called her friend maniac and then s/he was asked why s/he behaved that way and s/he was made to apologize.

K2: They are not obeying, some are using bad language, there are ones who hit to peers, some stick out their tongue when told to do something, talking loudly is prevalent, there are students who cry and thrash about on the ground when s/he is not satisfied. 
K2: three students jumped on jigsaws and broke them. I tried to talk but they did not listen to me. So, I punished them. They watched their friends playing. After the play, I talked again. They apologized this time.

\section{Findings Regarding Interventions to Misbehaviors in Classroom Management and Their Success Level}

Findings regarding the second research question are provided in Table 2.

Table 2

Interventions to Student Misbehaviors

\begin{tabular}{lll}
\hline Intervention & Frequency & Result \\
\hline Relaxation/penalty corner & 10 & Effective \\
One-to-one talking/forcing apology & 4 & Effective \\
Raising voice & 3 & Ineffective \\
Not including to activities & 2 & Effective \\
Different methods in separating to groups / explaining activities & 2 & Effective \\
Deprivation & 2 & Effective \\
Monotonous speaking & 2 & Ineffective \\
Warning (open) & 2 & Ineffective \\
Changing places & 2 & Effective \\
Not giving a sticker as a punishment & 1 & Ineffective \\
Ignoring & 1 & Ineffective \\
Child of the day (abstract reward) & 1 & Effective \\
Being determined & 1 & Effective \\
Talking & 1 & Ineffective \\
Making a promise & 1 & Effective \\
Giving sticker to the well-behaving (concrete reward) & 1 & Ineffective \\
\hline
\end{tabular}

Table 2 involves the interventions to prevent student misbehaviors practiced by teachers or pre-service teachers, their frequencies and efficiency level in eliminating the misbehaviors. To eliminate the student misbehaviors, the most favored intervention type was found as sending the students to relaxation/ penalty corner and making him/her wait there. The pre-service teachers who observed the lessons expressed that this type of intervention mostly yielded successful results. The second most frequent intervention type is talking one-to-one to the misbehaving child and getting him/her to apologize to related peer if necessary. This type of intervention was also found to be effective. It can be suggested that intervention types such as not including to activities, different methods in separating to groups/ telling activities, deprivation, changing the place of misbehaving student, abstract rewards like announcing the child of the day, making promises to motivate students, showing perseverance in decisions are effective in coping with student misbehaviors.

It is also found that intervention types such as raising voice or monotonous speaking, warning loudly in the class, giving/not giving stickers as a punishment or reward, ignoring and talking to all students are not that effective in dealing with student misbehaviors in preschool classroom management. Some of the answers provided by the participants regarding teacher interventions include the following.

K 4: ... There were students running in the classroom, they did not listen to the teacher. The teacher told she would give stickers to well behaving students, but they did not care. She wanted to play a game with them, but they didn't listen to her. She got angry. She made the misbehaving children sit on chairs and did not give stickers to them. I think this made things worse. A child cried.

K 5: ...two male children misbehaved, they spitted to their friend. One pushed his friend. They continued misbehaving despite the teachers' warnings. Then the teacher got them to sit at the corners and wait there. 


\section{K 5: ...I think reinforcement has an effect on misbehaviors.}

K 3: ... while separating the children to groups, the teacher made this by getting the children to pick cards and the children conformed to instructions amusedly.

Findings Regarding the Problematic Areas That the Pre-Service Teachers Experienced In Preschool Classroom Management during the Teaching Practice

Findings regarding the third research question are provided in Table 3.

Table 3

Problematic Areas Experienced by the Pre-Service Teachers during the Teaching Practice

\begin{tabular}{lll}
\hline Problematic area & Frequency & Source \\
\hline Crowded classroom & 6 & External \\
Catering to children's level & 5 & Self \\
Children's attention span & 3 & External \\
Impatient students & 3 & External \\
Reaction to peeing students & 1 & Self \\
Not knowing the students / not knowing enough meeting activities & 1 & Self \\
Children's not believing in pre-service teachers & 1 & External \\
Children's preference of competitive games & 1 & External \\
Constant student complaints & 1 & External \\
Transition between activities & 1 & Self \\
Coordinating group activities & 1 & Self \\
Children's inadequacy in some basic skills & 1 & External \\
Reacting to angry students & 1 & Self \\
Parents' complaints & 1 & External \\
Time management & 1 & Self \\
\hline
\end{tabular}

The most frequent problems as expressed by the pre-service teachers are problems related to crowded classes. Regarding the second most frequent problem area, which is catering to children's level, the participants stated that they had difficulty in instructing the game rules or activities to children. As they could not simplify their language so as the children to understand, they could not teach the rules or instructions. That the children's attention span is short, and they are impatient in games and activities are other problematic areas for pre-service teachers. Besides, some participants stated they were not sure of themselves when reacting to children who were angry at a moment or who peed in his/her pants. Children's not believing in pre-service teachers, their inadequacy in some skills (such as holding scissors), constant student complaints, and some parents' complaints created confusion for pre-service teachers in terms of deciding how to react at that very moments.

The problems experienced by pre-service teachers are grouped in this study based on whether they attributed the problem to external or internal sources (themselves indeed). The results suggest that the pre-service teachers think that the problems they experienced mostly stem from external sources. Crowded classrooms for instance, are one of the problems that don't stem from the pre-service teachers themselves. The participants mostly realized the problem areas related to themselves and they could generally reflect objectively and set goals to improve themselves in these areas. Some of the answers provided by the participants regarding the problems they experienced are as the following.

K2: The practice teacher is trying to take care of and communicate with each student but the number of the students in the class does not allow for this.

K3: ...my practice fellow raised her voice to be able to control the class but as she raised her voice, the children continued further to what they did. It did not work. 
K5: ...I think I need to learn more songs, videos, dance, games and activities that will attract children's attention.

K5: ...the children like outdoor games rather than in-class activities. I may learn different child games.

\section{CONCLUSION, DISCUSSION AND SUGGESTIONS}

The main goal in classroom management is to create an orderly and efficient classroom setting in order to enable desired behavioral changes in children eventually. When classroom management is inefficient, learning success will be low, students' motivation will be negatively affected and the aimed skills will not improve in the learning process (Başar, 2001; Çalık, 2012; Sadık, 2006). Teachers' management of classroom effectively has a critical impact on academic achievement and attitude towards school/learning (Marzano \& Marzano, 2003). If teachers have weakness in classroom management, they have to allocate time to prepare the student for instruction that they would otherwise spend for teaching (Öztürk, Gangal \& Beşken Ergişi, 2014). Therefore, given the prominence of the classroom management for education and need for more research regarding preschool context, this study addresses preschool classroom management. Based on senior pre-service preschool teachers' observation and experiences during teaching practice course, the present study set out to examine student misbehaviors confronted in preschool classrooms, intervention types to these misbehaviors, and the problematic areas that pre-service teachers experienced in preschool classroom management during the teaching practice.

In the current study, it was first aimed to explore what the student misbehaviors are in preschool education classrooms. The findings suggest that the most frequent student misbehavior at preschool level is violence towards peers. These behaviors mostly involve pushing friends, spitting, hitting or throwing toys at them. The second most frequent misbehavior is swearing or using bad language towards peers. Not participating to activities and constant crying and yelling are among the prevalent misbehaviors. These findings refer to the fact that the student misbehaviors at this level are mostly performed towards peers.

Öztürk, Gangal and Beşken Ergişi (2014) listed the most frequent student misbehaviors at preschool level as being uninterested, aggressive behaviors and stubbornness. These are listed as disobeying to rules and complaining by Dal and Akman (2018), constant complaints by Gangal (2013), distracting instruction, problems among peers and giving harm to surroundings by Uysal, Akbaba-Altun and Akgün (2009), and naughtiness, walking around, indifference, talking with friends, talking off topic, bantering, making noise, occupying teacher and not participating to activities by Nezihoğlu and Sabanc1 (2010). This shows that the findings in the present study are in line with the findings in the literature regarding the student misbehaviors at preschool level.

Secondly, interventions to prevent student misbehaviors practiced by teachers or pre-service teachers, their frequencies and efficiency level in eliminating the misbehaviors are explored in this study. The most frequent intervention type was reported as sending the student to relaxation/penalty corner and making him/her wait there to eliminate the student misbehaviors. The observing pre-service teachers stated that this type of intervention was mostly successful. The second most frequent intervention type was found as talking one-to-one to the misbehaving child and getting him/her to apologize to related peer or teacher if needed. This also had a positive effect on the misbehavior. However, practices of concrete rewards and punishments (i.e giving or not giving stickers) were not successful in overcoming the misbehaviors. In addition, talking to class about misbehaviors, general warnings, and loud talking were observed to be ineffective. Besides, being dedicated in maintaining the intervention is quite significant. 
Akgün, Yarar and Dinçer (2011) identified that teachers used negative strategies and verbal warnings more in in-class activities. Öztürk and Gangal (2016) and Kapucuoğlu Tolunay (2008) put forth that teachers tended to directly interfere with children's behaviors by resorting to traditional classroom management strategies. It is also highlighted in the literature that teachers behaved reactively while interfering in misbehaviors in classroom management, and they resorted to type one punishment and verbal/non-verbal warning strategies rather than teaching the right behavior (Bulut \& İflazoğlu, 2007; Dobbs, Arnold \& Doctoroff, 2004; Sadık, 2003; Uysal, Akbaba-Altun \& Akgün, 2010). As also suggested in this study, these types of interventions do not culminate in effective and lasting behavioral changes. While interfering with misbehaviors, the right behavior should be taught to students and more preferably it should be modelled by the teacher (Erdem, 2019).

Dal and Akan (2018) stated in their study that reward and reinforcement were used most frequently by teachers to prevent student misbehaviors. Gangal (2013), on the other hand, found that teachers used warning and reminding the rules the most when coping with misbehaviors. The results of the current study suggest that use of negative strategies and generally talking or making speeches or raising voice are not efficient in eliminating the misbehaviors. Accordingly, it is understood that teachers should avoid interfering attitudes in classroom management and should help students gain their own selfcontrol in accordance with their needs.

In another study, Polat, Kaya and Akdağ (2013) indicated that in theoretical assessments, pre-service teachers did not adopt rules-consequences model which is based on behaviorism and which argues that student behaviors are formed by extrinsic motivation; however, they added that pre-service teachers who had taken teaching practice course were more prone to adopting this model than ones who had not. Taking precautions before the occurrence of misbehaviors is the other side of classroom management. Öngören Özdemir and Tepeli (2016) found that most of the teachers did not take any precautions to prevent the occurrence of student misbehaviors and they mostly focused on behaviors. It was determined that the strategies employed by teachers after the misbehaviors eliminated the misbehaviors only temporarily and they reoccurred after some time.

Thirdly, the problems experienced by pre-service teachers during teaching practice with regard to preschool classroom management were explored in the current study. It is found that the pre-service teachers reported their problems they confronted in teaching practice under two categories. The first of these is factors that are out of control of pre-service teachers, external factors in other words. The most frequent of them are crowded classes, short time span of children's attention and children's impatience. In the second category, internal factors namely, the pre-service teachers mostly reported the cases when they felt they were not ready to act and their inadequacy in related skills in these cases. These factors include catering to children's levels in instruction, designing effective ways to get to know the students, competition, or group activities, making smooth transitions between activities, time management and reacting appropriately to students in unexpected cases.

The pre-service teachers firstly stated that they experienced problems during teaching practice due to some unexpected external cases and conditions. They, secondly, realized that they experienced problems due to their inadequacies of skills and practice regarding how they should react to some cases in the instruction process that indeed occur quite a lot. They found some solutions for these problems and yet these solutions led to some additional problems. Öztürk, Gangal and Beşken Ergisi (2014) argue that some of the student misbehaviors may stem from the practices of teachers. This means that teachers' behaviors have a huge impact on students' behaviors, particularly for students at the preschool level. Therefore, the appropriate activities utilized by teachers in class have the functions of preventing student misbehaviors and contributing to classroom management. In the same fashion, the current study reveals that pre-service teachers' inadequacies of knowledge and experience regarding these types of activities affected their classroom management skills. The pre-service teachers 
reflected their inadequacies successfully and they admitted that they had to improve themselves. Besides, they expressed in the meetings that the teaching practice extremely contributed to them. Yet, they were not interested in finding solutions for external factors maybe because of the fact that they thought they didn't have anything to do about them.

Similar to the findings in this study, Şahin Sak (2015) identified that pre-service teachers tend to consider themselves as inadequate. What lie under these beliefs are their lack of experience and the feeling of inefficacy in intervening to students who distract the order in the classroom. The literature has support for the arguments that pre-service teachers lack adequate classroom management skills and they have negative perceptions towards their teaching competences since they experience uncertainty in finding and practicing the right strategies (Ergünay, 2018; Güvendir, 2017; Kozikoğlu, 2016).

The number of the students is the most frequent problem area in the current study. In the literature, it is argued that teachers' classroom management performance lowers as the number of the students increase (Ercoşkun, 2011), and when the number of the students exceeds 20 (İlgar, 2007). There are other studies supporting these claims, as well (Dinçer \& Akgün, 2015; Nur, 2012). Şahin, TantekinErden \& Akar (2011) also identified that the preschool teachers stated that the number of the students is one of the basic elements of classroom management.

The effective coping strategies with student misbehaviors can also be accounted for the experience factor. That the pre-service teachers in this study who had teaching practice experience for the first time had failure in practicing the most efficient way in dealing with these behaviors may have to do with the fact that they did not have sufficient experience yet. Dinçer and Akgün (2015) determined that teachers who had six or more years of experience has higher levels of classroom management skills than teachers who had five or less years of experience. There are studies in the literature suggesting that classroom management skills differ significantly in terms of seniority variable. These studies argue that teachers can find better strategies for coping with student misbehaviors as their seniority increases (Akın, 2006; İlgar, 2007; Komitoğlu, 2009; Korkut \& Babaoğlan, 2010; O’Brien \& Goddard, 2006; Yaşar Ekici, Günhan \& Anılan, 2017; Yeşilyurt \& Çankaya, 2008).

Another factor related to teachers' effective ways of coping with student misbehaviors is the quality of pre-service teacher education. In the literature, pre-service teacher education is criticized as it cannot equip pre-service teachers with needed skills due to practice inadequacies (Ayvac1, Bakırc1 \& Y1ldı, 2014; Ertürk et al., 2014; Göksoy, 2014; Karasolak, Tanriseven \& Konokman, 2013; Kıranlı \& Yıldırım, 2014; Koçyiğit \& Eğmir, 2019). Increasing teaching practice opportunities for pre-service teachers and guiding them in forming instructional strategies in pre-service teacher education will ensure effective preparation of pre-service teachers for teaching profession.

Some studies in the literature suggest that in-service training for teachers contribute to their forming effective classroom management strategies and student misbehaviors decreased in the classes after the teachers received this education (Carter, Van Norman \& Tedwell, 2010; Slider, Noell \& Williams, 2006; Yeşilay Daşıran, 2013). Özgan and Yılmaz (2009) examined supervisors' opinions with respect to teachers' inadequacies in classroom management and suggested that teaching practice courses should be prioritized in pre-service education at universities and teachers should receive in-service education. As a result, it can be said that improving the pre-service and in-service teacher education is crucial for an effective classroom management as well, among all other things. As Musa \& Martha (2020, p. 4), suggested, it should be noted that "there is no education system that can rise higher than that of its teacher". 


\section{REFERENCES}

Akgün, E., Yarar, M. \& Dinçer, Ç. (2011). The evaluation of classroom management strategies of preschool teachers in classroom activities. Pegem Education and Training Journal, 1(3), 1-9.

Akın, U. (2006). The Relationship between teachers' classroom management skills and job satisfactions. (Unpublished Master's Thesis) Gaziosmanpaşa University, Social Sciences Institute, Tokat.

Avşar, P. (2011). Physical education teacher's evaluation of in-service training programme. Journal of National Education, 191, 230-241.

Ayvac1, H. S., Bakırc1, H. \& Yıldız, M. (2014). Science and technology teachers views and expectations about in-service training practices. Amasya Education Journal, 3(2), 357-383.

Başar, H. (2001). Classroom management. Ankara: Publications of the Ministry of Education.

Bilir, Ş. (1993). The importance and benefits of preschool education, preschool education. Ankara: M.E.B. Preschool Education General Directorate Publications.

Bulut, M. S. \& İflazoğlu, A. (2007). Problem behaviors that kindergarten teachers and prospective teachers face in the classroom and the strategies they develop for these behaviors: a qualitative study example. In N. Aral and B. Tuğrul (Eds.) Symposium book for the present and future of pre-school education in the European Union process. İstanbul: Ya-Pa.

Carter, D. R., Van Norman, R. K. \& Tredwell, C. (2011). Program-wide positive behavior support in preschool: Lessons for getting started. Early Childhood Education Journal, 38, 349-355

Carter, K. \& Doyle, W. (2006). Classroom management in early childhood and elementary classrooms. In C. M. Evertson, and C. S. Weinstein, (Eds.), Handbook of Classroom Management: Research, Practice, and Contemporary Issues, pp. 373-406. New Jersey: Lawrence Erlbaum.

Celep, C. (2002). Classroom management and discipline. Ankara: Anı Publishing.

Çalık, T. (2012). Basic concepts of classroom management. In L. Küçükahmet (Ed.) Classroom management (pp.1-16), Ankara: Pegem Publishing.

Dal, M. \& Akan, D. (2018). Classroom management strategies used to deal with unwanted behaviors encountered by pre-school teachers. International Journal of Human Sciences, 15(2), 1116-1128.

Dinçer, Ç. \& Akgün, E. (2015). Developing a classroom management skills inventory for preschool teachers and the correlation of preschool teachers' classroom management skills with different variables. Education and Science, 40(177), 187-201.

Dobbs, J, Arnold, D. H. \& Doctoroff, G. L. (2004). Attention in the preschool classroom: the relationships among child gender, child misbehavior, and types of teacher attention. Early Child Development and Care, 174(3), 281-295.

Durmuşoğlu Saltal, N. \& Arslan, E. (2013). The rules pre-school teachers establish for their classes and their application. Elementary Education Online, 12(4), 1032-1040.

Ercosskun, M. H. (2011). Examining the new roles of classroom teachers in maintaining effective classroom management. Unpublised Doctoral Dissertation. Atatürk University, Institute of Educational Sciences, Erzurum.

Erdem, C. (2019). Management of students' behaviors. In M. Koçyiğit (Ed.) Classroom management. Konya: Eğitim Publishing. 
Erdem, C. \& Koçyiğit, M. (2019). Student misbehaviors confronted by academics and their coping experiences. Educational Policy Analysis and Strategic Research, 14(1), 98-115. DOI: 10.29329/epasr.2019.186.6

Erdoğan, İ. (2001). Sınıf yönetimi: Ders, konferans, panel ve seminer etkinliklerinde başarının yollart. [Classroom management: Ways to success in lecture, conference, panel and seminar activities] İstanbul: Sistem Publishing.

Ergünay, O. (2018). Examining the first-year teaching experiences of beginning teachers with Hammerness, darling-Hammond and Bransford teacher education model: A multi-case study. Unpublished Doctoral Dissertation. Anadolu University, Eskişehir.

Erol, Z. (2006). Primary school teachers views on the application of class management, Unpublished Master's Thesis. Afyon Kocatepe University, Institute of Social Sciences, Afyonkarahisar.

Ertürk, H. G., Özen Altınkaynak, Ş., Veziroğlu, M., \& Erkan, S. (2014). A study on the views of preschool teachers on the effects of their university experiences on their professional lives. Kastamonu Education Journal, 22(3), 897-908.

Gangal, M. (2013). Investigating teachers' practices towards dealing with unwanted behaviors in classrooms in relation to their classroom management strategies in early childhood education. Unpublished Master's Thesis. Karadeniz Technical University, Intitute of Educational Sciences, Trabzon.

Göksoy, S. (2014). Teacher's comments on the process and the results of theIn-service training studies. International Journal of Human Sciences, 11(1), 387-402.

Güney, B. (2018). Views of the classroom teachers on the inservice training programs (Sample of Mardin, Midyat)). Unpublished Master's Thesis. İnönü University, Malatya.

Güvendir, E. (2017). Beginning english teachers and their problems, Dumlupınar University Journal of Social Sciences, 52, 74-94.

Hännikäinen, M. (2007). Rules and agreements and becoming a preschool community of learners. European Early Childhood Education Research Journal, 13(1), 97-110.

Ilgar, L. (2007). A research classroom management skills of primary school teachers. Unpublished Doctoral Dissertation. İstanbul University, Institute of Social Sciences, İstanbul.

Kapucuoğlu Tolunay, A. (2008). Student misbehaviours the primary teachers encounter in the classroom and the methods they use to cope with them. Unpublished Master's Thesis, Uludağ University, Institute of Social Sciences, Bursa.

Karadağ, R. (2015). Primary school teachers' views on and needs for in-service teacher training regarding turkish teaching. Inönü University Journal of the Faculty of Education, 16(3), 33-50.

Karasolak, K., Tanriseven, I. \& Yavuz Konokman, G. (2013). Determining teachers' attitudes towards inservice education activities. Kastamonu Education Journal, 21(3), 997-1010.

Kıranlı, S. \& Yıldırım, Y. (2014). Comparison of Teachers and School Administrators Opinions Related to In-Service Training Activities. Journal of Dicle University Ziya Gökalp Faculty of Education, 23, 219-251.

Koçyiğit, M. \& Eğmir, E. (2019). Teachers' Experiences in Pre-Service Training: An Analysis on Teacher Training. Mediterranean Journal of Educational Research, 13(30), 320-346. 
Komitoğlu, D. (2009). The investigation of the relationship between the classroom management abilities and the personality traits of classroom teachers. (The example of Kadlköy district, the city of Istanbul). Unpublished Master's Thesis. Yeditepe University, Insitute of Social Sciences, İstanbul.

Korkut, K. \& Babaoğlan, E. (2010). Sınıf öğretmenlerinin sınıf yönetimi becerisi [Classroom teachers' classroom management skills], Dumlupinar University Journal of Social Sciences, 2(26), 146-156.

Kozikoğlu, İ. (2016). First year in teaching: Challenges faced by novice teachers, their pre-service education's competency and commitment to the profession. Unpublished Doctoral Dissertation. Yüzüncü Y1l University, Institute of Educational Sciences, Van.

Manning, M. L. \& Bucher, K. T. (2013). Classroom management: Models, applications and cases (Third edition). NJ: Pearson \& Merrill Prentice Hall, Upper Saddle River.

Marzano, R. J. \& Marzano, J. S. (2003). The key to classroom management. Educational Leadership, 61(1), 6-13.

Miles, M. B. \& Huberman, A. M. (1994). Qualitative data analysis. Thousand Oaks: Sage Publication.

MoNE. (2017). General competences of the teaching profession. Ankara: General Directorate of Teacher Training and Development.

MoNE. (2013). Preschool education program. Ankara: National Education Publishing.

Musa, M. \& Martha, A. A. (2020). School management mechanisms and control of discipline among pupils in primary schools: An analysis of discipline in upper primary level. Anatolian Journal of Education, 5(1), 1-16. https://doi.org/10.29333/aje.2020.511a

Nezihoğlu, G. \& Sabanc1, A. (2010). Views of School Managers about Primary School Students' Misbehaviours and Their Strategies to Cope With. Pamukkale University Journal of Education, 28, 41-53.

Nur, İ. (2012), Examination of relationship between organizational climate and teachers' classroom management skills in kindergardens: The example of Malatya. Unpublished Master's Thesis, İnönü University, Institute of Educational Sciences, Malatya.

O'Brien, P. \& Goddard, R. (2006). Beginning teachers: Easing the transition to the classroom. The Australian Educational Leader, 28(1) 28-31.

Öngören Özdemir, S. \& Tepeli, K. (2016). Examining the Strategies of Preschool Teachers to Cope with Aggressive Behaviors. Ahi Evran Unv. Journal of Kırşehir Faculty of Education, 17(2), 51-70.

Özaydın, L. \& Çolak, A. (2011). The Views of Preschool Education Teachers over Mainstreaming Education and over In-service Education Program of Mainstreaming Education at Preschool Education. Kalem Journal of Education and Human Sciences, 1(1), 189-226.

Özgan, H. \& Y1lmaz, S. (2009). The perception of instructors about teacher's deficiencies of classroom management. Journal of Ahi Evran University Kirşehir Faculty of Education, 10(2), 57-65.

Öztürk, Y. \& Gangal, M. (2016). Preschool Teachers' Beliefs about Discipline, Classroom Management, and Disruptive Behaviors. Hacettepe University Journal of Education, 31(3), 593-608.

Öztürk, Y., Gangal, M. \& Beşken Ergişi, M. B. (2014). The Impact of Teaching Education Program on Pre-service Teachers' Classroom Management Views and Classroom Management Strategies. Erzincan University Faculty of Education, 16(1), 224-238. 
Özyürek, M. (2013). Olumlu sınıf yönetimi (4th ed.). Ankara: Kök Yayınlar1.

Polat, S., Kaya, S. \& Akdağ, M. (2013). Investigating pre-service taechers' beliefs about classroom discipline. Educational Sciences: Theory \& Practice, 13(2), 877-890.

Sad1k, F. (2006). The Investigation of students' misbehaviors and strategies to cope with misbehaviors according to teachers', students and parents' perspectives and the effects of assessertive discipline model based training program on teachers' discipline strategies. Unpublished Doctoral Dissertation, Çukurova University, Adana.

Sadık, F. (2003). Okul öncesi sınıflarda gözlenen problem davranışlar ve bu davranışlarla baş etmede ögretmenlerin kullandıkları yöntemler [Problem behaviors observed in preschool classrooms and methods used by teachers to deal with these behaviors]. Eğitim Araştırmalarl Dergisi [Journal of Educational Research], 13, 88-97.

Sezer, E. (2006). Ministry of education, state schools $\square$ guidance couselors and psychological consultants $\square$ views regarding in-service training (The case of Istanbul)). Unpublished Doctoral Dissertation. Yeditepe University, İstanbul.

Slider, N.J., Noell, G. H., \& Williams, K. L. (2006). Providing practicing teachers classroom management professional development in a brief self-study format. Journal of Behavioral Education. $15,215-228$.

Soleimani N. \& Razmjoo, A. (2016). Classroom management challenges: An account of efl teachers at private language institutes. Anatolian Journal of Education, 1(1), 51-69. https://doi.org/10.29333/aje.2016.114a

Şahin Sak, İ. T. (2015). Pre-Service Preschool Teachers' Self-Efficacy Beliefs about Classroom Management. Sakarya University Faculty of Education Journal, 29, 101-120.

Şahin, İ. T., Tantekin-Erden, F. \& Akar, H. (2011). The influence of the psysical environment on early childhood education classroom management. Eurasian Journal of Educational Research, 44, 185-202

Taba, S., Castel, A., Vermeer, M., Hanchett, K., Flores, D. \& Caulfield, R. (1999). Lighting the path: Developing leadership in early education. Early Childhood Education Journal, 26(3), 173-177.

Uysal, H., Akbaba-Altun, S. \& Akgün, E. (2009). Okulöncesi ögretmenlerinin çocukların istenmeyen davranışları karşısında uyguladıklarl stratejiler [The strategies that preschool teachers apply to the unwanted behavior of children]. Ege University 18. Educational Sciences Congress. İzmir: Ege University Faculty of Education

Weinstein, C. S., Romano, M. \& Mignano, A. J. (2011). Elementary classroom management: Lessons from research and practice. New York: McGraw-Hill.

Yaşar Ekici, F., Günhan, G. \& Anılan, Ş. (2017). Preschool teachers' clasroom manangement skills. Journal of The International Scientific Researches, 2(1), 48-58.

Yavuzer, H. (2006). Child education handbook. İstanbul: Remzi Publishing.

Yazdi, Z. A., Ghanizadeh, A., \& Mousavi, V. (2019). Assertive classroom management: how does it mould students' perceptions of classroom activities and goal orientations? Anatolian Journal of Education, 4(2), 39 52. https://doi.org/10.29333/aje.2019.425a

Yeşilay Daşıran, T. (2013). Okul öncesi eğitimde etkili sınıf yönetimi becerilerini geliştirmeye yönelik hazırlanan eğitimin etkililiğinin incelenmesi [Examining the effectiveness of education prepared to 
develop effective classroom management skills in preschool education]. Unpublished Master's Thesis. Ankara University, Ankara.

Yeşilyurt, E. \& Çankaya, İ. (2008), Determining teachers' qualities in the aspect of classroom management. Electronic Journal of Social Sciences, 7(23), 274-295.

Yin, R.K. (2003). Case study research: Design and methods. London: Sage Publications. 